\title{
Medieval Philosophical Discourse and Muslim-Christian Dialogue
}

\author{
Mehdi Aminrazavi
}

As pluralistic societies in the West become the norm and the "global village" becomes a reality, ecumenical dialogues gain prominence. Ecumenical dialogues, which, like many other discussions, first began among scholars as an exclusively academic activity, now take place in churches, communities, and other sociopolitical organizations. In the United States, in particular, attempts are being made to introduce educational curricula that are sensitive to the culture and religious orientations of minorities.

The very feasibility of a Christian-Muslim dialogue should be called into question. Can the Islamic world enter into a dialogue with the secular West? Any dialogue or discourse requires a cormmon language, a shared worldview, and some basic agreement on some of the fundamental axioms around which a worldview is formed. I fear that the Islamic world and the West no longer have such a common language.

In the present discussion, 1 will offer an analysis and interpretation of Muslim-Christian dialogue that calls for a reflection on the readiness of Muslims to have a meaningful dialogue with the West. I argue that the necessary condition for a meaningful dialogue between traditional Islam and the secular West does not exist and, therefore, that any attempt to do so at this time either will not succeed or will become a superficial survey of what we have in common, such as the Ten Commandments. To elucidate, I will first offer a model of a successful dialogue between Muslims and Christians based on the medieval philosophical dialogue between Muslim and Christian philosophers. I will then apply the conclusions drawn from this model to contemporary attempts at such ecumenical dialogues.

Any student of medieval philosophy can observe two distinct periods in the history of medieval philosophy, defined here as early and later, each of which has distinct characteristics. The early period belongs to the Church fathers who laid the groundwork for Christian philosophical and theological frameworks. Early Christian philosophical writings of such figures as Augustine, Boethius, John Scotus, St. Anselm, Peter Abaillard, and others were responses to specific questions of an intellectual nature. 
Of course, Greek philosophy and its proponents in Christendom were clearly there, but, as their works reflect, Christian philosophers merely adopted certain concepts from Greek philosophers in order to offer a rational defense of the faith. Early Christian philosophy, having been influenced by the Greeks alone, dealt with specific issues and attempted to find solutions to problems that Christianity was facing. In this regard, the two civilizations, Greek and Christianity, were engaged in a dialogue that was immensely beneficial to the enrichment of Christian intellectual thought.

On the Islamic side, such early Muslim philosophers as al Kindi and al Fārābī also followed the same pattern, namely, their views, concerns, and comments were responses to Greek philosophers, in particular Plato and Aristotle. When reading early Islamic philosophy, one clearly gets the impression that it too was engaged only with the Greeks and that their central concerns became the Muslims' central concerns as well. Clearly, some sort of dialogue was taking place between Muslims and Greeks on the philosophical level simply because Muslims needed to learn the discursive method of the Greek philosophers in order to defend, in a rational manner, the tenets of the faith. The two cultures differed profoundly, which made the dialogue both necessary and fruitful. This was necessary, since the perspective of one culture (Greek) was intellectually stimulating, and it was fruitful since it was through this philosophical dialogue that Muslim philosophers were able to adopt the Greek worldview and reinterpret it within the Islamic religious universe.

As examples of this dialogue, we can mention such figures as al Fārābī, Ibn Sīnā, al Ghazzālì, and Suhrawardì, each of whom confronted the Greek challenge in a different way. Al Fārābì, the founder of logic in the tradition of Islamic philosophy, elaborated on Aristotle's logic on the one hand and adopted the neo-Platonic schemes and Plato's concept of archetypes on the other. This allowed him to engage the Greek philosophical tradition in a dialogue and yet to Islamicize that tradition. Ibn Sinā, the grand synthesizer, effectively brought together Plato, Aristotle, and neoPlatonic ideas as well as al Fārābī into a single coherent paradigm. The coherency, consistency and the depth of Ibn Sinna's engagement with Greek philosophy was such that it became a turning point in the history of Islamic philosophy.

Much can be said about Ibn Sinna and his encounter with the Greeks and other intellectual ideas, but this is beyond the scope of this work. Suffice it to say that Ibn Sinna and the Greeks had a common language, objectives, and concerns and therefore operated in the same intellectual universe, although there were major differences between them. This point is of great significance in our discussion of a Muslim-Christian dialogue.

Following Ibn Sĩnā, the Muslim philosopher who epitomizes ecumenical dialogue between the Islamic intellectual tradition and that of other traditions, such as the Zoroastrian, neo-Platonic, Greek, and Pythagorean, is none other than Shihāb al Din Suhrawardi. To prove that the inner dimen- 
sion of all divinely revealed religions is sacred and a manifestation of the divine, Suhrawardi synthesized various elements of the above-mentioned traditions: He adopted Aristotelian logic (which he nevertheless criticized), Plato's theory of archetypes, elements from the Pythagoreans, Ibn Sinā's ontological hierarchy (which he modified), and various elements from other traditions. Suhrawardi's vast synthesis of philosophical and mystical elements resulted in the formation of a new philosophical paradigm that is both profoundly Islamic and ecumenical in nature. What allowed him to borrow and synthesize philosophical concepts from other traditions was that he felt at home with the spiritual and intellectual message of these other schools of thought and religious traditions.

Let us now proceed and consider later medieval Christian philosophy in order to examine the extent to which Islamic and Christian philosophers have influenced each other. St. Thomas Aquinas presents a perfect picture of a philosopher whose works are not only influenced by Greek philosophy but also by Islamic philosophy. He learned much from al Fārābī's logical treatise and borrowed much of Ibn Sīnā's ontological scheme. His Summa Theologica bears the influence and the impact of Islamic philosophy upon him, although he expressed repeatedly that he detested Islam as a religion. With the influence of Islamic philosophical thought on much of Aquinas's writings, the picture that emerges is that of a person who, despite vast religious differences with Islam nevertheless shared with it a sacred universe and a common language. Thus, he was able to use the findings of such a religious adversary as Ibn Sinnā. To this equation, one can even add Moses Maimonides, who shared this sacred worldview and language, as his writings bear testament.

A brief glance at the history of medieval intellectual thought reveals an ecumenical dialogue between East and West that communicated with each other because they shared a common language. It is precisely this common language that allowed two distinct traditions to communicate with one another.

The common sacred language and universe of the Islamic-Christian religious universe broke down following the end of the medieval period in Europe. With the Reformation and the Renaissance, Europe marginalized religion and thereby determined the social direction toward which Europe would begin its intellectual journey. With the Renaissance, Europe ended its common language with Islam and thereafter made a concerted effort to shift the focus of its civilization from theos to anthropos. This shift was a return to the Greek intellectual world in which man is the only measure of things, and thus the West began to criticize itself through Greek eyes. What is noteworthy and apparent in this deconstructionist effort of the Enlightenment is the reliance on the humanistic secularism of the Greeks. This time, however, it was not used to construct a dialogue between Greek thought and the Christian worldview, but rather to "deconstruct," "demythologize," "de-mystify," and, finally, to destroy Christianity. 
Following the Renaissance, the West chose a different intellectual paradigm. It also changed the language with which it had communicated with other civilizations as well as with its own past. The changing of a common language between this secular and newly converted West and other civilizations that had retained God as the center of its universe resulted in the end of communication. Perhaps nowhere was the impact of this profound change more drastic than on Islamic civilization, which remained staunchly theocentric. It is a symbolic coincidence that René Descartes, the father of modern Western philosophy who introduced the notion of "doubting anything that can be doubted," is a contemporary of the grand metaphysician of Islam, Sadr al Din Shirāzī (Mullā Șadrā), who advocated the attainment of certainty through intellectual intuition.

It would not be unreasonable to say that since the Renaissance, Islam and the West have found no common language with which to communicate. Even throughout the medieval period, which often symbolizes the conflicts between Islam and Christianity, a traditional Muslim and a Christian would have found very little about which to disagree, particularly regarding moral rights and wrongs. In the post-Renaissance era, however, Muslims and Westerners find very little to agree upon, a condition that has produced a great deal of tension, as noted by S. Huntington in his article "The Clash of Civilizations."

This brings us to a problem that we face in our contemporary attempts to have an ecumenical dialogue with the West, in general, and the Christian West, in particular. The West has a greater degree of tolerance for accepting "the other" precisely because it has undergone the experiences of Reformation and Renaissance. Such a metamorphosis has made the West value-free and therefore more accepting of the new "isms" than the Islamic Weltanschaaung, which is divided strictly along the sacred and the profane. How can the Islamic world, which has gone in a different direction during the last four centuries, communicate with the modern West, which has abandoned the sacred and thereby eliminated that which was held in common? In fact, the modern secular West is not any more capable of having a discourse with its own fundamentalists and defenders of God than it is of having a discourse with Muslims.

An objection that is often raised to such a thesis cites the nonmonolithic nature of Western societies as evidence. The United States, in particular, has one of the highest rates of church attendance, and the "moral majority" is alive and well. While it is true that there are practicing Christians in the West, one can question the intention and the purpose of a dialogue among those who, esentially, are in agreement and share a common set of moral principles. One motive for such a dialogue is to arrive at a theological middle ground. In fact, the theological differences between Christianity and Islam are insoluble, and any attempt to bridge the gap becomes an attempt at conversion. The other motive for a dialogue with 
the Christian West would be for its utility, namely, world peace. Such noble concepts as peace and tranquillity are sufficiently meritorious in themselves that one can, and should, do everything possible to actualize them. If, however, the understanding of one another and world peace is facilitated by an understanding of one another's faith, then such a dialogue is prudent and should be pursued.

The real dialogue, however, which is essential if Muslims are to function in the contemporary world, is with modernity and the culture it has engendered. By and large, Christianity has embraced modernity and, to a great extent, has adopted its dictums, whereas Islam remains defiant with respect to modernity and refuses to accept it. This defiance of modernity should not be mistaken with the rejection of technology; it is a rejections of the culture that comes with modernity.

A dialogue between Islam and the modern world is indeed a short one. Part of this brevity has to do with Islam's rejection of modernity as evil and decadent. The fact that Islam has a strong legal side and that the Shari'ah defines the permissibility and the limits of human activity leaves no room for a gray area in which a dialogue can occur. To elaborate further on the nature of a dialogue between traditional Islam and the modern world, let us consider a hypothetical conversation between a traditional Muslim (M) and a secular Westerner (W):

W: What do you think about the West?

M: The West is morally corrupt, decadent, and the culture of "sex, drugs, and rock and roll" that it advocates is demonic.

W: What do you think about democracy?

M: Democracy, in the sense of allowing individuals to be free so they can be decadent, is not allowed in Islam.

W: What about the inalienable right of individuals, such as the right to choose one's lifestyle, how to dress, and so on?

M: God, through the Shari'ah, has determined the limits of such rights. In Islam, all rights belong to God.

$\mathrm{W}$ : Are boys and girls allowed to mingle?

M: No, the Shari'ah does not allow this.

W: Are homosexuals allowed to adhere to their sexual orientation?

M: No, according to the Shari'ah they should be put to death.

C: What are your views on media and what they broadcast?

M: The media should only broadcast what is consistent with the Shariah.

End of discussion between traditional Islam and the modern West! 
For a Muslim, the Shari'ah has determined right from wrong and true from false. Therefore, there is no room for a discourse with a world that thrives on change, holds the view that "anything goes," and argues for relativity in various domains, especially as regards ethics and epistemology. Islam and the modern West neither share a common worldview nor adhere to the same norms; therefore, the possibility of a meaningful dialogue between them does not exist. This presents us with a complex situation that is of the utmost significance if Muslims, in general, and those living in the West are to survive and not live marginally on the fringes of society.

The absence of a common language through which Muslims can understand and be understood by the West has manifested itself in the rise of two different groups of Muslims. There are those who, because of the existing problems, reject "the West" entirely and, as a reaction to it, stand at opposite pole. These "born-again Muslims," to borrow a term from Christianity (whom the media calls "fundamentalists"), are an alien and new concept in Islam. The moral chaos in the West so frightens them that they consider the Shari'ah to be the absolute and perennial law of Islam. From this comes a total rejection of modernity, which replaces "truth" with "truths" and produces hostility to the West as a civilization within which modernity harbors and prospers.

The second group of Muslims are those who become conformists and integrate fully into the mainstream Western lifestyle. This group is convinced that religion is a thing of the past, is inconsistent with reason and rationality, and is a cause for embarrassment among the more educated and academically oriented people. Certainly, mainline academics view persons with truly religious convictions as a species whose survival defies evolution! This group of Muslims embraces the West and the culture of modernity with open arms, as a substitute for religious despotism, and considers Promethean freedom to be possible only in the death of the sacred.

Neither the first nor the second group is interested in a dialogue with the West. The central question for Muslims in the beginning of the third millennium is how should a third group, one that is interested in preserving its religious heritage and yet remaining part of modern society, live? What should the intellectual foundations of this group be? What is to be tolerated, and how can the Shari'ah be reinterpreted to make it possible for the emergence of Muslims who can function in a modern setting? To this end, jurists (fuqahä') bear most of the responsibility, for their extensive use and reliance upon ijtihad can provide the tools with which Muslims can cope and come to terms with modernity. The search for a niche within which Muslims can take refuge and stay unaffected by the modern world has failed. As those who have tried to create various versions of an Islamic state have found out, modernity is not a passive phenomenon; on the contrary, it is aggressive and challenges traditional values. 
A middle ground must be found, one where Muslims, in general, and Muslims living in the West, in particular, can remain within the pale of Islam and come to terms with modernity. Otherwise, we will suffer the same fate as our medieval ancestors did in Andalusia-conversion or expulsion. This time, however, we are not asked to convert to Christianity but to modernity and secularism, and there is nowhere to be expelled to where modernity does not exist.

\section{Endnotes}

1. Samuel P. Huntington, "The Clash of Civilizations," Foreign Affairs (Summer 1993): 22-49. 